\title{
Genetic polymorphism of $A L D H 2$ linkage to kidney function status of East Nusa Tenggara alcohol drinkers and cigarette smokers
}

\author{
Busyra, ${ }^{1, *}$ Yudha Nurhantari, ${ }^{1}$ Suhartini, ${ }^{1}$ Maria Agnes Etty Dedy, ${ }^{2}$ and Tri Ratnaningsih ${ }^{3}$ \\ ${ }^{1}$ Department of Forensic and Medicolegal, Faculty of Medicine, Public Health, and Nursing, Universitas Gadjah Mada, \\ Yogyakarta, Indonesia \\ ${ }^{2}$ Department of Medicine, Faculty of Medicine, University of Nusa Cendana, Kupang, Indonesia \\ 3Department of Clinical Pathology, Faculty of Medicine, Public Health, and Nursing, Universitas Gadjah Mada, \\ Yogyakarta, Indonesia
}

KEYWORDS

Alcohol

ALDH2 gene

Cigarette smoking

Kidney function
ABSTRACT Chronic kidney disease is a preventable high-burden disease. Several risk factors for impaired kidney function have been identified, including lifestyles, such as alcohol drinking and cigarette smoking. However, the evidence remains inconsistent. East Nusa Tenggara has the largest proportion of heavy alcohol drinking among all provinces in Indonesia. Genetic polymorphism of aldehyde dehydrogenase $2(A L D H 2)$ is related to alcohol drinking behavior through the inactivity of the ALDH2 enzyme, which leads to toxic acetaldehyde accumulation. This study aims to recognize the linkage of $A L D H 2$ genotypes to kidney function among alcohol drinkers and cigarette smokers in East Nusa Tenggara. This study was a cross-sectional study of East Nusa Tenggara ethnicity, aged 18-60 years old. Demographic and lifestyle data were obtained via a questionnaire. DNA analysis was conducted with the polymerase chain reaction-restriction fragment length polymorphism (PCR-RFLP) technique. Creatinine and BUN levels were measured with a chemistry analyzer. Afterward, the estimated glomerular filtration rate (eGFR) was calculated from creatinine value using the Chronic Kidney Disease Epidemiology Collaboration (CKD-EPI) equation. The association between kidney function status and alcohol drinking and cigarette smoking habits were analyzed using the chi-square test, then stratified based on genotype groups. Fifty-one subjects were included in this study, while the mean age was $26.33 \pm 1.33$ years and the median age was 22 years. There were $37(72.5 \%)$ alcohol drinkers and 14 (27.5\%) non-drinkers; $28(54,9 \%)$ cigarette smokers and $23(45.1 \%)$ non-smokers. This study revealed no significant association between kidney function status and alcohol drinking habits. Cigarette smoking habits were inversely associated with eGFR decline and creatinine elevation in wild-type ALDH2 groups.

(C) The Journal 2021. This article is distributed under a Creative Commons Attribution-ShareAlike 4.0 International license.

\section{Introduction}

Chronic kidney disease (CKD) is associated with the abnormality of kidney function, marked by the decline of glomerular filtration rate (GFR) and albuminuria. The pathophysiology of CKD involves several mechanisms, including inflammation, toxin exposure, hyperfiltration, and hypertrophy of the nephrons. Some identifiable risk factors of CKD are hypertension, diabetes mellitus, autoimmune disease, advanced age, and genetic. ${ }^{1}$ Lifestyle factors,

\footnotetext{
*Correspondence: busyra_b@yahoo.com

Department of Forensic and Medicolegal, Faculty of Medicine Public Health, and Nursing, Universitas Gadjah Mada, Jl. Farmako, Sekip Utara, Yogyakarta 55281, Indonesia
}

such as alcohol drinking and cigarette smoking habits, are also related to several chronic diseases. However, previous studies investigating the relationship between these lifestyle factors and CKD showing inconsistent results. ${ }^{2,3,4}$ In 2019, National Health Insurance recorded more than 1.7 million cases of CKD in Indonesia, which cost more than 2.3 trillion rupiahs. CKD became the fourth catastrophic disease after heart disease, cancer, and stroke. ${ }^{5}$

As a Muslim-majority country, alcohol consumption in Indonesia is relatively low. Nonetheless, some provinces have relatively higher alcohol consumption. The province with the highest rate of alcohol consumption is North Sulawesi (16\%), followed by East Nusa Tenggara (15.6\%) and Bali 
(14\%). However, East Nusa Tenggara has the largest proportion of heavy alcohol drinking, of $3.2 \%$, while the proportion in North Sulawesi is $2.4 \%{ }^{6}$

Acetaldehyde, a by-product of ethanol metabolism, is responsible for the unpleasant symptoms after alcohol consumption, such as facial flushing, nausea, and tachycardia. Subsequently, acetaldehyde will be oxidized by the aldehyde dehydrogenase (ALDH) enzyme, mainly the class II isozyme (ALDH2), which is coded by the ALDH2 gene. Genetic polymorphism of $A L D H 2$ is related to alcohol drinking behavior through the inactivity of the ALDH2 enzyme, which leads to toxic acetaldehyde accumulation. Hypothetically, the unpleasant sensations of acetaldehyde accumulation will prevent further alcohol consumption. ${ }^{7}$

The prevalence of genetic polymorphism depends on race or ethnicity. Genetic polymorphism of ALDH2 in the East Asian population has a larger proportion than in the European or African population, approximately $28-45 \% .{ }^{8}$ Previous studies in different ethnicities in Indonesia showed that $72.9 \%$ of subjects of Javanese and $35.9 \%$ of subjects of Papua ethnicity have at least one polymorphic ALDH2 allele. ${ }^{9,10}$ While Java is located in the western part of Indonesia and Papua in the eastern part of Indonesia, there are differences in genetic profile and culture. Despite being in the eastern part of Indonesia, East Nusa Tenggara is known as the melting pot, showing high cultural diversity and evidence of genetic admixture. ${ }^{11,12}$

This study aims to recognize the linkage of $A L D H 2$ genotypes to kidney function among alcohol drinkers and cigarette smokers in East Nusa Tenggara. Considering the difference $A L D H 2$ gene profile among the populations, the susceptibility to develop diseases may be different. By identifying the $A L D H 2$ gene profile of East Nusa Tenggara, specific advice related to lifestyle risk factors to kidney impairment can be delivered to the population.

\section{Method}

The study design was cross-sectional. Samples were selected by consecutive sampling techniques. Inclusion criteria of the subjects were people of East Nusa Tenggara ethnicity, aged $18-60$ years old, not pregnant, and consented to be part of the study. The exclusion criteria were people with underlying kidney disease. Demographic and lifestyle data, including alcohol drinking and cigarette smoking habits, were obtained via a questionnaire. Five $\mathrm{ml}$ of venous blood were collected in two vacutainers containing EDTA for DNA analysis and gel separator for chemistry analysis.

Data and samples were collected in October 2019 in Kupang, East Nusa Tenggara. We arranged with heads of local neighborhoods and Bakunase Public Health Center (PHC) to invite the accessible population. It was located in the Bakunase subdistrict, which was approachable and had capacious PHC. Interviews were conducted to select the subjects that met all eligibility criteria and having informed about the study. Questionnaires and blood samples were taken after the subjects consented to participate.

DNA analysis was conducted with the polymerase chain reaction-restriction fragment length polymorphism (PCR-RFLP) technique. DNA was extracted from leucocytes using Wizard ${ }^{\circ}$ Genomic DNA Purification Kit (Promega; Madison, USA). ALDH2 gene was amplified with the PCR method, using a forward primer of 5'-CAA ATT ACA GGG TCA AGG GCT-3' and a reverse primer of 5'-CCA CAC TCA CAG TTT TCT CTT-3'. The PCR products were subsequently digested by Mboll restriction enzyme and visualized in FloroSafe (First Base; Selangor, Malaysia) stained 3\% agarose with a gel documentation system. The uncut $A L D H 2$ gene was 135 bp long. Mboll recognition sites were $5^{\prime} \ldots$...AAGA(N) $8 *$... $3^{\prime}$ in forward primer and $3^{\prime} \ldots$ $\mathrm{CTTCT}(\mathrm{N}) 7^{*} \ldots 5^{\prime}$ in reverse primer, resulting in two bands of $125 \mathrm{bp}$ and $10 \mathrm{bp}$. Mboll cut the ALDH2*1 allele, or wild-type allele, while the $A L D H 2 * 2$ or polymorphic allele remained uncut. ${ }^{13}$

Creatinine and blood urea nitrogen (BUN) levels were measured with a chemistry analyzer from blood serum. Creatinine was examined using Creatinine FS reagent (DiaSys; Holzheim, Germany), then measured with photometry method. While BUN was examined using Urea FS reagent (DiaSys; Holzheim, Germany), then measured with colorimetry method. The reference values for creatinine were 0.7-1.2 $\mathrm{mg} / \mathrm{dl}$ for male and 0.5-0.9 mg/dl for female. The reference value for BUN was $20-35 \mathrm{mg} / \mathrm{dl}$. Afterward, 
estimated GFR (eGFR) was calculated from creatinine value using the Chronic Kidney Disease Epidemiology Collaboration (CKD-EPI) equation.

Kidney function status was defined by elevated creatinine \& BUN level and the decline of eGFR $(<90$ $\mathrm{ml} / \mathrm{min} / 1.73 \mathrm{~m}^{2}$ ). The association between kidney function status and alcohol drinking and cigarette smoking habits were analyzed using the chi-square test, then stratified based on genotype groups. The differences were defined as significant if the $p$-value was $<0.05$ ( $95 \%$ confidence interval).

This study has been approved by The Medical and Health Research Ethics Committee, Faculty of Medicine, Public Health, and Nursing, Universitas Gadjah Mada (letter-number KE/FK/0830/EC/2019).

\section{Result}

\subsection{Subjects' characteristics}

Fifty-one subjects met inclusion and exclusion criteria, consists of 40 male and 11 female subjects. The mean age of the subjects was $26.33 \pm 1.33$ years and the median age 22 years. There were 37 (72.5\%) alcohol drinkers and 14 (27.5\%) non-drinkers; 28 $(54,9 \%)$ cigarette smokers and 23 (45.1\%) nonsmokers. Most of the drinkers and smokers were male. Only one female subject drinks alcohol, and none of them were cigarette smokers. Of 28 cigarette smokers, 27 of them were alcohol drinkers.

From DNA analysis, we found 27 (52.9\%) subjects with $A L D H 2 * 1$ or wild-type $A L D H 2$ gene. Genetic polymorphism of $A L D H 2$ was found in 24

Table 1. Subjects' characteristics based on ALDH2 genotypes

\begin{tabular}{|c|c|c|c|c|}
\hline \multirow[b]{2}{*}{ Variables } & \multicolumn{4}{|c|}{ ALDH2 Genotypes } \\
\hline & $\begin{array}{l}1-1 \\
n(\%)\end{array}$ & $\begin{array}{l}1-2 \\
n(\%)\end{array}$ & $\begin{array}{l}2-2 \\
n(\%)\end{array}$ & $\begin{array}{l}\text { Total } \\
\text { n (\%) }\end{array}$ \\
\hline $\begin{array}{l}\text { Male } \\
\text { Female }\end{array}$ & $\begin{array}{l}22(43,1) \\
5(9,8)\end{array}$ & $\begin{array}{l}6(11,8) \\
1(2,0)\end{array}$ & $\begin{array}{l}12(23,5) \\
5(9,8)\end{array}$ & $\begin{array}{l}40(78,4) \\
11(21,6)\end{array}$ \\
\hline $\begin{array}{l}\text { Drinkers } \\
\text { Non-drinkers }\end{array}$ & $\begin{array}{l}22(43,1) \\
5(9,8)\end{array}$ & $\begin{array}{l}5(9,8) \\
2(3,9)\end{array}$ & $\begin{array}{l}10(19,6) \\
7(13,7)\end{array}$ & $\begin{array}{l}37(72,5) \\
14(27,5)\end{array}$ \\
\hline $\begin{array}{l}\text { Smokers } \\
\text { Non-smokers }\end{array}$ & $\begin{array}{l}16(31,4) \\
11(21,6)\end{array}$ & $\begin{array}{l}5(9,8) \\
2(3,9)\end{array}$ & $\begin{array}{l}7(13,7) \\
10(19,6)\end{array}$ & $\begin{array}{l}28(54,9) \\
23(45,1)\end{array}$ \\
\hline
\end{tabular}

1-1: wild-type; 1-2: heterozygous atypical; 2-2: homozygous atypical

Table 2. Kidney function status associated with the alcohol drinking habit

\begin{tabular}{|c|c|c|c|c|c|}
\hline \multirow[b]{2}{*}{ Variables } & \multicolumn{2}{|l|}{ eGFR } & \multirow[b]{2}{*}{$\begin{array}{l}\text { Total } \\
\text { n (\%) }\end{array}$} & \multirow[b]{2}{*}{ p-value } & \multirow[b]{2}{*}{$\begin{array}{l}\text { OR } \\
(95 \% \mathrm{Cl})\end{array}$} \\
\hline & $\begin{array}{l}<90 \\
n(\%)\end{array}$ & $\begin{array}{l}\geq 90 \\
\mathrm{n}(\%)\end{array}$ & & & \\
\hline \multirow{2}{*}{$\begin{array}{l}\text { Drinkers } \\
\text { Non-drinkers }\end{array}$} & $13(25.5)$ & $24(47.1)$ & $37(72.5)$ & \multirow{3}{*}{$>0.05$} & \multirow{3}{*}{$\begin{array}{l}0.542 \\
(0.156-1.884)\end{array}$} \\
\hline & 7 (13.7) & $7(13.7)$ & $14(27.5)$ & & \\
\hline \multirow[t]{3}{*}{ Total } & $20(39.2)$ & $31(60.8)$ & $51(100)$ & & \\
\hline & \multicolumn{2}{|l|}{$\mathrm{Cr}$} & & & \\
\hline & $\begin{array}{l}\text { Increased } \\
\mathrm{n}(\%)\end{array}$ & $\begin{array}{l}\text { Normal } \\
\mathrm{n}(\%)\end{array}$ & & & \\
\hline \multirow{2}{*}{$\begin{array}{l}\text { Drinkers } \\
\text { Non-drinkers }\end{array}$} & 9 (17.6) & $28(54.9)$ & $37(72.5)$ & \multirow{3}{*}{$>0.05$} & \multirow{3}{*}{$\begin{array}{l}0.321 \\
(0.089-1.167)\end{array}$} \\
\hline & 7 (13.7) & 7 (13.7) & $14(27.5)$ & & \\
\hline \multirow[t]{3}{*}{ Total } & $16(31.4)$ & $35(68.6)$ & $51(100)$ & & \\
\hline & \multicolumn{2}{|l|}{ BUN } & & & \\
\hline & $\begin{array}{l}\text { Increased } \\
\mathrm{n}(\%)\end{array}$ & $\begin{array}{l}\text { Normal } \\
\text { n (\%) }\end{array}$ & & & \\
\hline \multirow{2}{*}{$\begin{array}{l}\text { Drinkers } \\
\text { Non-drinkers }\end{array}$} & $14(27.5)$ & $23(45.1)$ & $37(72.5)$ & \multirow{3}{*}{$>0.05$} & \multirow{3}{*}{$\begin{array}{l}0.812 \\
(0.233-2.832)\end{array}$} \\
\hline & $6(11.8)$ & $8(15.7)$ & $14(27.5)$ & & \\
\hline Total & $20(39.2)$ & $31(60.8)$ & $51(100)$ & & \\
\hline
\end{tabular}


Table 3. Kidney function status associated with the cigarette smoking habit

\begin{tabular}{|c|c|c|c|c|c|}
\hline \multirow[b]{2}{*}{ Variables } & \multicolumn{2}{|l|}{ eGFR } & \multirow[b]{2}{*}{$\begin{array}{l}\text { Total } \\
\text { n (\%) }\end{array}$} & \multirow[b]{2}{*}{ p-value } & \multirow[b]{2}{*}{$\begin{array}{l}\text { OR } \\
(95 \% \mathrm{Cl})\end{array}$} \\
\hline & $\begin{array}{l}<90 \\
n(\%)\end{array}$ & $\begin{array}{l}\geq 90 \\
n(\%)\end{array}$ & & & \\
\hline \multirow{2}{*}{$\begin{array}{l}\text { Smokers } \\
\text { Non-smokers }\end{array}$} & $7(13.7)$ & $21(41.2)$ & $28(54.9)$ & \multirow{3}{*}{$<0.05$} & \multirow{3}{*}{$\begin{array}{l}0.256 \\
(0.078-0.841)\end{array}$} \\
\hline & $13(25.5)$ & 10 (19.6) & $23(45.1)$ & & \\
\hline \multirow[t]{3}{*}{ Total } & $20(39.2)$ & $31(60.8)$ & $51(100)$ & & \\
\hline & \multicolumn{2}{|l|}{$\mathrm{Cr}$} & & & \\
\hline & $\begin{array}{l}\text { Increased } \\
\mathrm{n}(\%)\end{array}$ & $\begin{array}{l}\text { Normal } \\
\mathrm{n}(\%)\end{array}$ & & & \\
\hline \multirow{2}{*}{$\begin{array}{l}\text { Smokers } \\
\text { Non-smokers }\end{array}$} & $5(9.8)$ & $23(45.1)$ & $28(54.9)$ & \multirow{3}{*}{$<0.05$} & \multirow{3}{*}{$\begin{array}{l}0.237 \\
(0.067-0.842)\end{array}$} \\
\hline & $11(21.6)$ & $12(23.5)$ & $23(45.1)$ & & \\
\hline \multirow[t]{3}{*}{ Total } & $16(31.4)$ & $35(68.6)$ & $51(100)$ & & \\
\hline & \multicolumn{2}{|l|}{ BUN } & & & \\
\hline & $\begin{array}{l}\text { Increased } \\
\mathrm{n}(\%)\end{array}$ & $\begin{array}{l}\text { Normal } \\
\mathrm{n}(\%)\end{array}$ & & & \\
\hline \multirow{2}{*}{$\begin{array}{l}\text { Smokers } \\
\text { Non-smokers }\end{array}$} & 9 (17.6) & $19(37.3)$ & $28(54.9)$ & \multirow{3}{*}{$>0.05$} & \multirow{3}{*}{$\begin{array}{l}0.517 \\
(0.165-1.615)\end{array}$} \\
\hline & $11(21.6)$ & $12(23.5)$ & $23(45.1)$ & & \\
\hline Total & $20(39.2)$ & $31(60.8)$ & $51(100)$ & & \\
\hline
\end{tabular}

Table 4. Stratification analysis of eGFR associated with cigarette smoking habit based on ALDH2 genotypes

\begin{tabular}{|c|c|c|c|c|c|c|}
\hline \multirow[b]{2}{*}{ Variables } & & \multicolumn{2}{|l|}{ eGFR } & \multirow{2}{*}{$\begin{array}{l}\text { Total } \\
\text { n (\%) }\end{array}$} & \multirow[b]{2}{*}{ p-value } & \multirow{2}{*}{$\begin{array}{l}\text { OR } \\
(95 \% \mathrm{Cl})\end{array}$} \\
\hline & & $\begin{array}{l}<90 \\
n(\%)\end{array}$ & $\begin{array}{l}\geq 90 \\
n(\%)\end{array}$ & & & \\
\hline \multirow{3}{*}{$A L D H 2 * 1$} & Smokers & $3(11.1)$ & $13(48.1)$ & $16(59.3)$ & \multirow{3}{*}{$<0.05$} & \multirow{3}{*}{$\begin{array}{l}0.132 \\
(0.023-0.764)\end{array}$} \\
\hline & Non-smokers & 7 (25.9) & $4(14.8)$ & $11(40.7)$ & & \\
\hline & Total & $10(37.0)$ & $17(63.0)$ & $27(100)$ & & \\
\hline \multirow{3}{*}{$\operatorname{ALDH} 2 * 1 / 2 * 2$} & Smokers & $1(14.3)$ & 4 (57.1) & $5(71.4)$ & \multirow{3}{*}{$>0.05$} & \multirow{3}{*}{-} \\
\hline & Non-smokers & $0(0.0)$ & $2(28.6)$ & $2(28.6)$ & & \\
\hline & Total & $1(14.3)$ & $6(85.7)$ & $7(100)$ & & \\
\hline \multirow{3}{*}{$A L D H 2 * 2$} & Smokers & 3 (17.6) & $4(23.5)$ & $7(41.2)$ & \multirow{3}{*}{$>0.05$} & \multirow{3}{*}{$\begin{array}{l}0.500 \\
(0.070-3.550)\end{array}$} \\
\hline & Non-smokers & $6(35.3)$ & $4(23.5)$ & $10(58.8)$ & & \\
\hline & Total & 9 (52.9) & $8(47.1)$ & $17(100)$ & & \\
\hline \multirow{3}{*}{ Total } & Smokers & 7 (13.7) & $21(41.2)$ & 28 (54.9) & \multirow{3}{*}{$<0.05$} & \multirow{3}{*}{$\begin{array}{l}0.256 \\
(0.078-0.841)\end{array}$} \\
\hline & Non-smokers & $13(25.5)$ & 10 (19.6) & $23(45.1)$ & & \\
\hline & Total & $20(39.2)$ & $31(60.8)$ & $51(100)$ & & \\
\hline
\end{tabular}

eGFR: estimated glomerular filtration rate; Cr: creatinine; BUN: blood urea nitrogen; OR: odds ratio; $95 \%$ Cl: $95 \%$ confidence interval

(47.1\%) subjects, comprised 7 (13.7\%) heterozygous atypical $(A L D H 2 * 1 / 2 * 2)$ and $17(33.3 \%)$ homozygous atypical $(A L D H 2 * 2)$. The distribution of sex, alcohol drinking, and cigarette smoking habits among these ALDH2 genotype groups was presented in Table 1.

\subsection{Chi-square analysis of kidney function status}

Chi-square tests for kidney function showed no differences in eGFR decline, nor creatinine $(\mathrm{Cr})$ and BUN elevation between alcohol drinkers and non- alcohol drinkers, with p-value of $0.355,0.099$, and 0.758, respectively, as presented in Table 2.

The chi-square tests presented in Table 3 indicated that eGFR decline and creatinine elevation were statistically different between cigarette smokers and non-smokers, with p-value of 0.042 and 0.034 , respectively. The odds for eGFR decline and creatinine elevation were lower in the cigarette smoker group. However, there was no difference in BUN elevation between smoker and non-smoker groups, with a p-value of 0.388 . 
Table 5. Stratification analysis of creatinine associated with cigarette smoking habit based on ALDH2 genotypes

\begin{tabular}{|c|c|c|c|c|c|c|}
\hline \multirow[b]{2}{*}{ Variables } & & \multicolumn{2}{|l|}{$\mathrm{Cr}$} & \multirow[b]{2}{*}{$\begin{array}{l}\text { Total } \\
\text { n (\%) }\end{array}$} & \multirow[b]{2}{*}{ p-value } & \multirow[b]{2}{*}{$\begin{array}{l}\text { OR } \\
(95 \% \mathrm{Cl})\end{array}$} \\
\hline & & $\begin{array}{l}\text { Increased } \\
\mathrm{n}(\%)\end{array}$ & $\begin{array}{l}\text { Normal } \\
\mathrm{n}(\%)\end{array}$ & & & \\
\hline \multirow{3}{*}{$A L D H 2 * 1$} & Smokers & $1(3.7)$ & $15(55.6)$ & $16(59,3)$ & \multirow{3}{*}{$<0.05$} & \multirow{3}{*}{$\begin{array}{l}0.056 \\
(0.005-0.580)\end{array}$} \\
\hline & Non-smokers & $6(22.2)$ & 5 (18.5) & $11(40,7)$ & & \\
\hline & Total & 7 (25.9) & $20(74.1)$ & $27(100)$ & & \\
\hline \multirow{3}{*}{$A L D H 2 * 1 / 2 * 2$} & Smokers & $1(14.3)$ & $4(57.1)$ & $5(71,4)$ & \multirow{3}{*}{$>0.05$} & \multirow{3}{*}{-} \\
\hline & Non-smokers & $0(0.0)$ & $2(28.6)$ & $2(28,6)$ & & \\
\hline & Total & $1(14.3)$ & $6(85.7)$ & $7(100)$ & & \\
\hline \multirow{3}{*}{$A L D H 2 * 2$} & Smokers & $3(17.6)$ & $4(23.5)$ & $7(41,2)$ & \multirow{3}{*}{$>0.05$} & \multirow{3}{*}{$\begin{array}{l}0.750 \\
(0.107-5.238)\end{array}$} \\
\hline & Non-smokers & $5(29.4)$ & $5(29.4)$ & $10(58,8)$ & & \\
\hline & Total & $8(47.1)$ & $9(52.9)$ & $17(100)$ & & \\
\hline \multirow{3}{*}{ Total } & Smokers & $5(9.8)$ & $23(45.1)$ & $28(54,9)$ & \multirow{3}{*}{$<0.05$} & \multirow{3}{*}{$\begin{array}{l}0.237 \\
(0.067-0.842)\end{array}$} \\
\hline & Non-smokers & $11(21.6)$ & $12(23.5)$ & $23(45,1)$ & & \\
\hline & Total & $16(31.4)$ & 35 (68.6) & $51(100)$ & & \\
\hline
\end{tabular}

eGFR: estimated glomerular filtration rate; Cr: creatinine; BUN: blood urea nitrogen; OR: odds ratio; $95 \%$ Cl: $95 \%$ confidence interval

\subsection{Stratification analysis based on $A L D H 2$ genotypes}

Stratification analysis based on $A L D H 2$ genotype groups was performed to determine whether genetic polymorphism being a modifier or a confounding factor to the kidney function status. The analysis was conducted on statistically significant variables. The association between cigarette smoking habit and eGFR decline can be seen in Table 4. Meanwhile, the association between cigarette smoking habit and creatinine elevation can be seen in Table 5. Stratification analysis revealed a significant association between variables that appeared only in the $A L D H 2 * 1$ group, which was the wild-type $A L D H 2$ groups.

\section{Discussion}

The plausible explanation of alcohol consumption's effects on kidney function can be via oxidative stress. As one of the ethanol metabolism by-products is reactive oxygen species, cellular damage can occur in many organs. Diabetes mellitus and cardiovascular disease are well established as the major risk factors to CKD, while both diseases are also evidently induced by chronic and heavy alcohol consumption. ${ }^{14,15}$ However, some observational studies indicated no association or inverse association between alcohol drinking and kidney function status. Some studies suggested that heavy alcohol drinking can be related to kidney function impairment. ${ }^{2,3,16,17}$ Our study showed no significant association between alcohol drinking habit and kidney function status. It must be considered that the subjects of our study were dominated by young aged. Besides kidney function decline may not have appeared, the duration of alcohol consumption was relatively short.

The inverse association between cigarette smoking and eGFR decline and creatinine elevation was inconsistent with studies that found no relationship between cigarette smoking and CKD. ${ }^{4,18}$ Another study stated that smokers had a higher risk of developing CKD. This risk might be through the mechanism that smoking may cause insulin resistance and endothelial cell dysfunction, which lead to diabetes mellitus and cardiovascular disease. ${ }^{3}$

We conducted the stratification analysis based on the $A L D H 2$ gene, then found that cigarette smoking is inversely associated with eGFR decline and creatinine elevation only in wild-type $A L D H 2$ groups. Therefore, the $A L D H 2$ genotype should be considered to the decreased risk of kidney function impairment. This finding was similar to a study in Japan that indicated the significant association between homozygous atypical $A L D H 2$ and the decreased eGFR. ${ }^{19}$

Since the proportion of wild-type $A L D H 2$ genotype in East Nusa Tenggara was only $52.9 \%$, the decreased risk of kidney function impairment 
could not be guaranteed in every individual. Besides, we should also consider other adverse effects of cigarette smoking on the body and other risk factors beyond the scope of this study. There should be other considerations related to the established risk factors of CKD.

Genetic polymorphism of ALDH2 may be protective against heavy alcohol drinking behavior due to the accumulation of toxic acetaldehyde. Nevertheless, studies suggest that the environmental factor has a bigger impact than the genetic factor in influencing alcohol drinking habits. ${ }^{20,21}$ If the individuals were carrying polymorphic $A L D H 2$ allele drink alcohol, the risk of acetaldehyde accumulation increasing. It may lead to various chronic diseases. ${ }^{22}$

Alcohol consumption has been a part of the culture in East Nusa Tenggara. Alcoholic beverages always appear in traditional ceremonies. Alcohol is also a medium to mingle and socialize. ${ }^{23}$ Therefore, intervening in alcohol drinking habits in the East Nusa Tenggara population would not be easy. It should be regulated by the government or tribe leader to restrict underage drinkers, as well as to limit the amount and the ethanol content of alcoholic beverages consumed.

\section{Conclusion}

This study revealed no significant association between kidney function status and alcohol drinking habits. Cigarette smoking habits were inversely associated with eGFR decline and creatinine elevation in wildtype $A L D H 2$ groups.

Despite the findings in this study, cigarette smoking should not be encouraged because of its damage to other organs and systems. Moreover, the proportion of genetic polymorphism of $A L D H 2$ in East Nusa Tenggara was relatively high. However, the benefits or harms of chronic alcohol consumption should be explored more due to the absence of a relationship between alcohol consumption and kidney function status. Further study might be needed, with broader characteristics of subjects in East Nusa Tenggara, especially age and sex.

\section{Acknowledgement}

We would like to thank the East Nusa Tenggara project team, Laboratory of Clinical Pathology and Laboratory of Biochemistry, Faculty of Medicine, Public Health, and Nursing, Universitas Gadjah Mada, for their assistance. This study was funded by Penelitian Dasar Unggulan Perguruan Tinggi (PDUPT) Grant 2018-2019 from Simlitabmas Dikti, No. 45/ UNI/DITLIT/DIT-LIT/LT/2018.

\section{Conflict of interests}

The authors declare no conflict of interest.

\section{References}

1. Bargman JM, Skorecki KL. Harrison's principles of internal medicine. 20th ed. New York: McGrawHill Education, 2018. Chapter 305: Chronic Kidney Disease; p. 2111-21.

2. Buja A, Vinelli A, Lion C, Scafato E, Baldo V. Is moderate alcohol consumption a risk factor for kidney function decline? A systematic review of observational studies. J Ren Nutr. 2014;24(4):224-35.

3. Kelly JT, Su G, Zhang L, Qin X, Marshall S, GonzálezOrtiz A, et al. Modifiable lifestyle factors for primary prevention of CKD: A systematic review and meta-analysis. J Am Soc Nephrol. 2020;31.

4. Hill NR, Fatoba ST, Oke JL, Hirst JA, O'Callaghan CA, Lasserson DS, et al. Global prevalence of chronic kidney disease - A Systematic Review and Meta-Analysis. PLoS One. 2016;11(7):1-18.

5. Badan Penyelenggara Jaminan Sosial Kesehatan. Laporan pengelolaan program dan laporan keuangan (auditan) tahun 2019. Jakarta: BPJS Kesehatan; 2020.

6. Badan Penelitian dan Pengembangan Kesehatan. Laporan Nasional Riskesdas 2018. Jakarta: Lembaga Penerbit Badan Penelitian dan Pengembangan Kesehatan; 2019.

7. Quertemont E. Genetic polymorphism in ethanol metabolism: Acetaldehyde contribution to alcohol abuse and alcoholism. Mol Psychiatry. 2004;9(6):570-81.

8. Goedde HW, Agarwal DP, Fritze G, MeierTackmann D, Singh S, Beckmann $G$, et al. Distribution of $A D H 2$ and ALDH2 genotypes in different populations. Hum Genet. 1992;88(3):344-6. 
9. Suhartini, Mustofa, Nurhantari $Y$, Rianto BUD, Widagdo $H$, Agni IAW. Analysis of effect of aldehyde dehydrogenase 2 (ALDH2) gene polymorphism on liver function status of alcohol drinkers in Indonesia. AIP Conf Proc. 2019;2099.

10. Nugroho NA. Hubungan antara polimorfisme gen ALDH2 dengan kebiasaan minum alkohol pada mahasiswa Papua di Yogyakarta [master's thesis]. Yogyakarta: Universitas Gadjah Mada; 2018. 94 p.

11. Mona S, Grunz KE, Brauer S, Pakendorf B, Castr L, Sudoyo $\mathrm{H}$, et al. Genetic admixture history of eastern Indonesia as revealed by $\mathrm{Y}$-chromosome and mitochondrial DNA analysis. Mol Biol Evol. 2009;26(8):1865-77.

12. Karafet TM, Hallmark B, Cox MP, Sudoyo $H$, Downey S, Lansing JS, et al. Major eastwest division underlies y chromosome stratification across Indonesia. Mol Biol Evol. 2010;27(8):1833-44.

13. Tomita M, Okuyama T, Hidaka K, Ameno S, Ameno K, ljiri I. Application of capillary gel electrophoresis to the diagnosis of the aldehyde dehydrogenase two genotypes. J Chromatogr B. 1996;685:185-90.

14. Varga ZV, Matyas C, Paloczi J, Pacher P. Alcohol misuse and kidney injury: Epidemiological evidence and potential mechanisms. Alcohol Res Curr Rev. 2017;38(2).

15. World Health Organization. Global status report on alcohol and health 2018. Geneva: World Health Organization; 2018.

16. Lai YJ, Chen YY, Lin YK, Chen CC, Yen YF, Deng CY. Alcohol consumption and risk of chronic kidney disease: A nationwide observational cohort study. Nutrients. 2019;11,2121.

17. Cheungpasitporn W, Thongprayoon C, Kittanamongkolchai $W$, Brabec BA, O'corragain $\mathrm{OA}$, Edmonds PJ, et al. High alcohol consumption and the risk of renal damage: A systematic review and meta-analysis. Qjm. 2015;108(7):539-48.

18. Vupputuri S, Sandler DP. Lifestyle risk factors and chronic kidney disease. Ann Epidemiol. 2003;13(10):712-20.

19. Morita K, Oniki K, Miyazaki H, Saruwatari J, Ogata $\mathrm{Y}$, Mizobe $\mathrm{M}$, et al. Aldehyde dehydrogenase 2 as a potential protective factor for renal insufficiency in Japanese subjects with heart failure: a pilot study. J Hum Hypertens. 2014;28:279-81.

20. Ting $T$, Huang $S$, Chen $K$, Tseng $C$, Lin KM, Chen $\mathrm{CY}$, et al. Effects of genetic variants of $\mathrm{ADH} 1 \mathrm{~B}$ and ALDH2 and social network on continued alcohol drinking among young adolescents in Taiwan. Drug Alcohol Depend. 2015;147(155):38-45.

21. Dick DM, Kendler KS. The impact of geneenvironment interaction on alcohol use disorders. Alcohol Res Curr Rev. 2012;34(3):31824.

22. Zhao Y, Wang C. Glu504Lys single nucleotide polymorphism of aldehyde dehydrogenase 2 gene and the risk of human diseases. Biomed Res Int. 2015;2015:13-5.

23. Lette AR, Ratnawati AT, Swasti IK. Perilaku minum sopi pada remaja di Kecamatan Maulafa, Kota Kupang. Ber Kedokt Masy. 2016;32(7):237-44. 